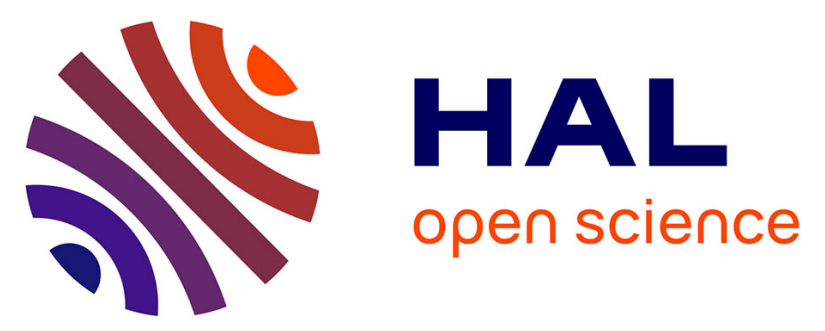

\title{
Investigation of inter-individual epigenetic variability in bovine clones: A high throughput study
}

Hélène Kiefer, Luc Jouneau, Marie-Laure Magniette Martin-Magniette, Sandrine Balzergue, Evelyne E. Campion, Pascale Chavatte-Palmer, Yvan Y. Heyman, Christophe Richard, Daniel D. Le Bourhis, Jean Paul J. P. Renard, et al.

\section{To cite this version:}

Hélène Kiefer, Luc Jouneau, Marie-Laure Magniette Martin-Magniette, Sandrine Balzergue, Evelyne E. Campion, et al.. Investigation of inter-individual epigenetic variability in bovine clones: A high throughput study. Annual Conference of the International Embryo Transfer Society, Jan 2013, Hanovre, Germany. pp.173, 10.1071/RDv25n1Ab51 . hal-01004742

\section{HAL Id: hal-01004742 https://hal.science/hal-01004742}

Submitted on 3 Jun 2020

HAL is a multi-disciplinary open access archive for the deposit and dissemination of scientific research documents, whether they are published or not. The documents may come from teaching and research institutions in France or abroad, or from public or private research centers.
L'archive ouverte pluridisciplinaire HAL, est destinée au dépôt et à la diffusion de documents scientifiques de niveau recherche, publiés ou non, émanant des établissements d'enseignement et de recherche français ou étrangers, des laboratoires publics ou privés. 
reprogramming in SCNT embryos has been suggested as a major reason for this low birth rate, we attempted to improve the success rate by using several lines of donor cells that were reprogrammed by gene transfection and an inhibitor treatment. First, the bovine ear fibroblast cells were transfected with vectors (pCX-OKS-2A and pCX-Myc) carrying 4 genes $(O c t-4, K l f 4$, Sox2, and c-Myc; OKSM). Subsequently, transfected cells were incubated in the presence of one of the following chemical inhibitors: (1) trichostatin A (TSA, 20 nM), (2) 5-aza-20-deoxycytidine (5-aza-dC, $10 \mu \mathrm{M}$ ), or (3) GSK-3/MEK inhibitor ( $2 \mathrm{i}$; GSK-3, $3 \mu \mathrm{M}$ and MEK, $1 \mu \mathrm{M}$ ) for 7 days. Throughout the incubation period, cells in each treatment group were analyzed for their histone acetylation status. Subsequently, transfected ceils were used as nucleus donors in SCNT and their development rates to the blastocyst stage were estimated. In the present study, it was found that the histone acetylation (H3K $9 / \mathrm{K} 14)$ levels were generally higher in treated groups compared with nontreated control groups. Regarding blastocyst development rate, the OKSM/5-aza-dC $(10 / 49,20.1 \pm 5.9 \%)$ combination was better than the other groups: OKSM/TSA $(8 / 77,11.1 \pm 6.9 \%)$, OKSM/2i $(8 / 84,9.5 \pm 1.5 \%)$, OKSM $(6 / 50,12.6 \pm 6.5 \%)$, and negative control group $(9 / 94,9.6 \pm 3.8 \% ; P<0.05)$. Embryo development rates appeared to be higher in OKSM/inhibitor-treated groups, although the rate was significantly lower $(P<0.05)$ in $\mathrm{OKSM} / 2 \mathrm{i}$. In conclusion, our data siggest that transfection with 4 genes and incubating with 5 -aza-dC can significantly improve the development rate of bovine SCNT embryos.

\title{
51 INVESTIGATION OF INTER-INDIVIDUAL EPIGENETIC VARIABILITY IN BOVINE CLONES: A HIGH THROUGHPUT STUDY
}

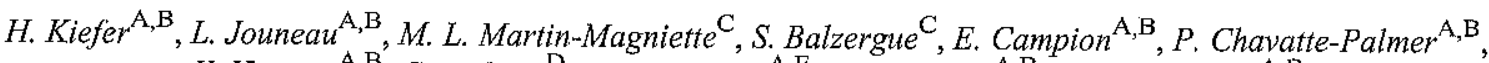 \\ Y. Heyman ${ }^{\mathrm{A}, \mathrm{B}}$, C. Richard ${ }^{\mathrm{D}}$, D. Le Bourhis ${ }^{\mathrm{A}, \mathrm{E}}, J$. P. Renard ${ }^{\mathrm{A}, \mathrm{B}}$, and H. Jammes ${ }^{\mathrm{A}, \mathrm{B}}$ \\ ${ }^{A}$ Biology of Development and Reproduction, Institut National de Recherche Agronomique, Jouy-en-Josas, France; \\ ${ }^{B}$ Ecole Nationale Vétérinaire de Maisons-Alfort, Maisons-Alfort, France; \\ ${ }^{C}$ URGV Institut National de Recherche Agronomique, Evry, France; \\ ${ }^{D}$ UCEA, Institut National de Recherche Agronomique, Leudeville, France; \\ ${ }^{\mathrm{E}}$ UNCEIA, Maisons-Alfort, France
}

\begin{abstract}
Reprogramming the differentiated cell to totipotency can be achieved following the introduction of its nucleus into an enucleated oocyte, a procedure known as cloning. We used cattle clones as a pertinent model to assess the inter-individual epigenetic variability and its consequences on phenotypes, including agronomically relevant traits and developmental pathologies. Indeed, the developmental defects frequently associated with cloning could be related to the insufficient extent of reprogramming, leading to perturbations of the nuclear microenvironment of the early embryo, with long-tern consequences on the phenotype. Immunoprecipitation of methylated DNA following hybridization on a new bovine-specific tiling array (MeDIPchip) was used to describe the epigenomic patterns affected by incomplete reprogramming. We first focused on the liver, because overgrowth of this organ is, to a certain extent, bound to global foetal overgrowth, which is often observed in clones. The microarray represents the 21416 bovine genes currently annotated (UMD3.1 genome assembly). Each gene was tiled by 34 probes, on average, spanning upstream regions from -2000 to $+1360 \mathrm{bp}$ relative to the transcription start site. This microarray was hybridized with MeDIP samples from livers of normal Holstein animals obtained by AI ( 4 perinatal controls and 8 adults: 2 males and 10 females) and livers of female Holstein clones ( 7 perinatal clones from 2 different genotypes, either stillborn or suffering from severe pathologies, and 7 adult clones from 3 different genotypes, with normal to pathological phenotypes). After normalization of the data, enriched probes were identified using the ChIPmix method (Martin-Magniette et al. 2008 Bioinformatics) and located on the Ensembl Genome Browser. Results of exploratory analysis, including correlation clustering, principal components analysis (PCA), and independent components analysis (ICA), will be presented. A statistical test based on differences in the spatial distribution of the enriched probes along promoters was applied to the data, to associate epigenetic signatures to specific parameters (cloning, phenotype, stage, and genotype). Most promoters with more than 5 enriched probes across individuals showed a clustered distribution of the enriched probes. This local enrichment was highly conserved among individuals for $96 \%$ of the promoters, suggesting that most of the methylated regions were common to all animals. More interestingly, the distributions of the enriched probes showed inter-individual variability for $4 \%$ of the promoters in all samples. The identification and validation of these promoters is currently in progress.
\end{abstract}

Funding was provided by ANR-09-GENM-012-01 and ACI-PHASE-INRA-2010.

\section{IMPLANTATION OF TRANSGENIC BOVINE CLONED EMBRYOS DERIVED FROM TRANSFECTED CELLS BY PIGGYBAC TRANSPOSITION}

\author{
$W . J$. Choi $^{\mathrm{A}}, S . J . L e e^{\mathrm{B}}, W . W . L e e^{\mathrm{A}, \mathrm{B}}, S . J . K_{i m}^{\mathrm{A}}, I . M$. Saadeldin $^{\mathrm{A}}, J . K . C h o^{\mathrm{C}}, B . C$. Lee $^{\mathrm{A}}$, and G. Jang ${ }^{\mathrm{A}}$ \\ ${ }^{A}$ Department of Theriogenology and Biotechnology, College of Veterinary Medicine and Research Institute for Veterinary Science, \\ Seoul National University, Seoul 151-742, Republic of Korea; \\ ${ }^{B}$ Embryo Research Center in Seoul Milk Coop., Gyeonggi-do, Republic of Korea; \\ CDepartment of Theriogenology, College of Veterinary Medicine, Chungnam National University, Daejeon, Republic of Korea
}

A gene-delivery system, PiggyBac (PB) transposition, has been applied to transgene expression in manmalian cells or animals. In this study, to produce transgenic cattle, we used $\mathrm{PB}$ in bovine fibroblasts and then the transfected cells were microinjected into enucleated bovine oocytes to produce embryos and offspring. For this study, 2 different finorescence genes (GFP, transcribed by constitutive promoter and $R F P$, transcribed by tetracycline-dependent promoter), which were flanked by PB sequences, were transfected into the bovine fetal fibroblasts by the FuGENE transfection protocol. The developmental rate of blastocysts among the cleaved embryos derived from $G F P$ cells and doxycycline-induced $R F P$ cells was developed at $23.1 \%(31 / 134)$ and $40.9 \%(442 / 1082)$, respectively. After transferring the GFP- or RFP-expressing blastocysts into recipient cows, 